\title{
In Memoriam J.W. (Pim) Schoorl (1927-2018)
}

\section{On the Move, Creating Space for Others}

\author{
Philip Quarles van Ufford
}

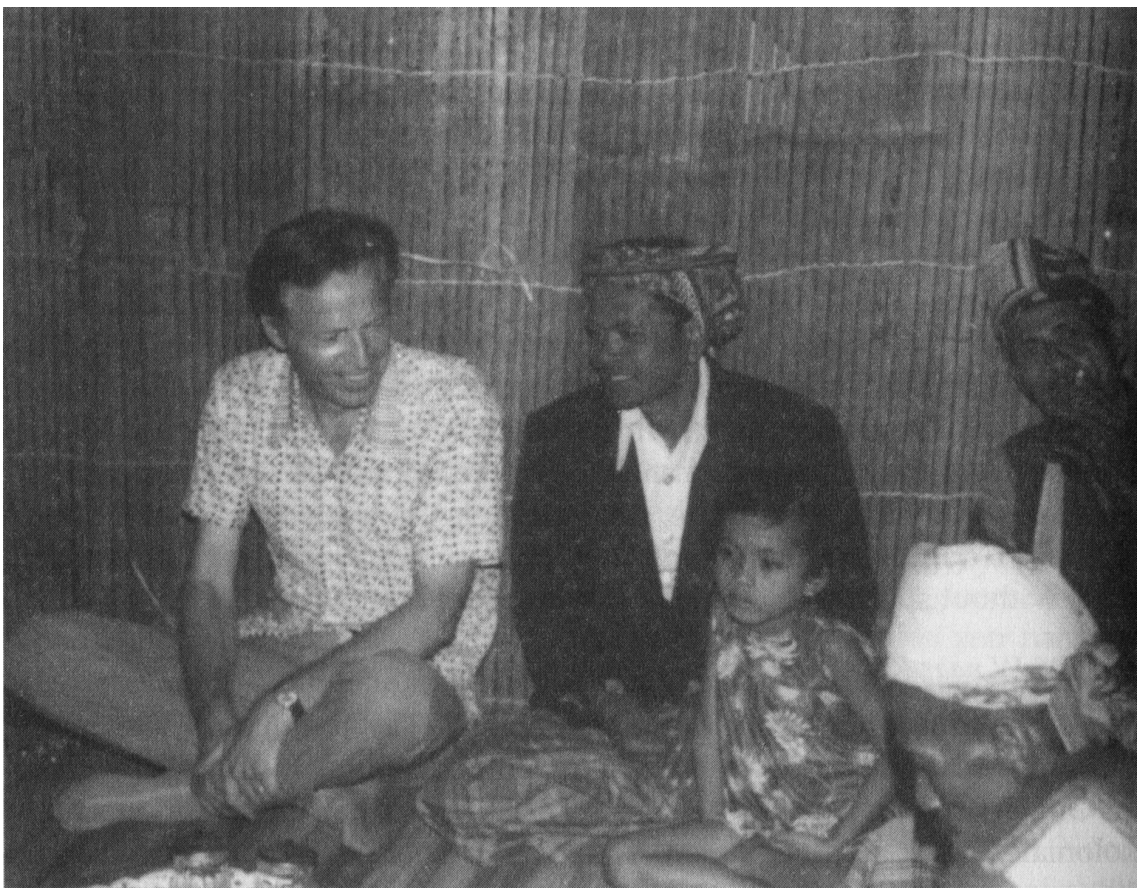

The death of Pim Schoorl, honorary member of the KITLV, on 28 April 2018, after a short illness, was unexpected and came as a shock. Schoorl had been with us more or less since his retirement, in 1988, from the role of professor of sociology of non-Western societies at the Vrije Universiteit Amsterdam (VU), where he was much respected for his many achievements. Schoorl had set up a lively Institute of Anthropology and Development Studies there and all the staff members honoured him on his retirement by contributing to a rich volume, titled Religion and development (Quarles van Ufford and Schoffeleers 1988). Lists were made of his publications and manifold administrative achievements at the vU and in Dutch academia more widely. Schoorl had

(C) PHILIP QUARLES VAN UFFORD, 2018 | DOI:10.1163/22134379-17404023

This is an open access article distributed under the terms of the prevailing CC-BY-NC license 
been awarded a civil honour for the second time, and was now a Ridder in de Orde van de Nederlandse Leeuw (Knight of the Order of the Netherlands Lion).

Schoorl retired rather early, at the age of 61 . This allowed him to return to his first love, Indonesia Studies, publishing on a variety of topics in this area, including Sufi mysticism on Buton, Indonesia; the Dutch colonial administration in Papua New Guinea; and culture and cultural change among the Muyu in Papua, an area he had administered earlier on in his career. He also became chairman of the board of the KITLV. As chairman he led the KITLV through a period of great stress to much greater security, both administratively and financially.

On his death, I would like to do more than list his achievements: I would like to examine what significance we must attribute to his work. The keen sense of loss felt by so many on his death indicates that many people benefited from his work in a deeper sense. Is it already possible to gain a more nuanced view of Pim Schoorl?

The subtitle of this in memoriam, 'On the move, creating space for others', sums up my view of his wider significance. Achievements, scientific and administrative, were not his ultimate goal; rather, they became stepping stones for him to create greater space and more freedom for other people. Creating greater space for others constituted the central purpose of his working life. Achievements as such were, of course, welcome, but he saw those primarily as a means to a bigger goal.

He was 'on the move'. I take issue with the rather conventional view that Schoorl was primarily a highly gifted administrator. Indeed, he was. Yet, I feel that this view misses the point. Administering mostly implies being pragmatic about accepting exisisting boundaries. Schoorl was, however, not a defender or an administrator of the status quo-political, scientific, or religious-but was always engaged in transforming it. He moved gently-listening, smilingand silent, if possible. But by doing so, all the time he was constantly 'nibbling' at the boundaries. He was a great nibbler of fences, always moving things on.

Schoorl resisted being enclosed by the restrictive limitations of the past, as well as by certainties concerning the future. He resisted acceptance of certified, sacralized views, dogmas, creeds, or paradigms - in short, any political, scientific, or religious claims of truth. Nor did he take his own past and loyalties as a secure point of departure for his work. He was aware of the risks of imposing himself and his views on others. His moral standpoint therefore differed from the 'ethical policy' implemented in Indonesia by the Dutch after 1901. This ethical policy, to a large extent, became a way to impose specific notions of the 
Western Christian or modern Self on Indonesians. In contrast, Schoorl's modesty never allowed him to lose his sense of responsibility, which also made him resistant to postmodern inclinations later on.

His close colleague early on at the vU, H.G. Schulte Nordholt, professor of anthropology, elegantly put it this way in 1988: Schoorl never succumbed to the truth-claims of any of the competing scientific paradigms. He was an 'administrator of scientific theories'. As a scientist he was a free man. Modest impetus; modest outcomes. His research was primarily directed by the need for 'reliable information'. Information, indeed, not 'data'; the distinction is important. As a man on the move, without a road map to the future, with no more than a sense of direction, hope, and a promise, perhaps, he needed information. His mentor Jan van Baal had taught him so. One needs reliable 'information' to give substance to the responsibility for others. He travelled gently, cautiously, and always with an open mind. In sum, his morally informed, modest, gentle, and open style of work, and his willingness to move across boundaries, constituted his significance.

Studying Indologie at Leiden University, 1946-1951

His choice of study, Indologie (Indology), at Leiden University in 1946 was remarkable. Indology had been set up to prepare students for a role in the colonial administration in the Dutch East Indies. But now, in 1946, with Indonesia having proclaimed its independence, war with the Dutch seemed imminent. Why, then, did Schoorl decide to study Indology? Was he preparing himself for a role in the colonial administration after political 'order' had been restored? While this goal of restoring order was endorsed by most people in the Netherlands, Schoorl's motives were different. Like many Leiden academics, Schoorl did not support Dutch policy in Indonesia; besides, the prospect of obtaining a job in the colonial administration was becoming unrealistic.

After graduation, Schoorl started looking for a job in the Netherlands. He sent a great number of applications to Dutch government bodies, as well as to large businesses, such as Philips. In the letters he suggested that his study of other cultures would be relevant for the job. His personal archive contains a great number of applications, together with mostly gently formulated negative responses. It must have been a difficult time for him. Yet Schoorl persisted, widening his network. For instance, he wrote to the new Wereldraad van Kerken (World Council of Churches; hereafter wCC), which had been set up in 1948, contacting the theologian J.C. Hoekendijk. This was a remarkable 
step, as Hoekendijk, representing the WCC in Batavia in 1945, was openly critical of Dutch government policy vis-à-vis Indonesia. Hoekendijk also advocated for a fundamental reassessment of Dutch missionary policies. This was anathema to the Netherlands Reformed Churches. ${ }^{1}$ Hoekendijk, prominent in the Nederlandse Hervormde Kerk (Netherlands Reformed Church; hereafter NRC), supported a rather drastic, decolonizing transformation of Indonesian-Dutch missionary relations.

On his graduation, Schoorl, who had been a member of the Gereformeerde Kerken (Reformed Churches in the Netherlands; hereafter RCN) since his birth, made contact with progressive Reformed theologians, such as Joh. Bavinck, to whom the restoration of Dutch colonial order was also not self-evident. He asked for advice in his search for a meaningful job and for other contacts. He also approached J.E. van den Berg, who had just established the first office for international aid. Schoorl's mind was clearly open to new beginnings. Meanwhile, Schoorl kept his distance from the missionary advisers of his own RCN, which at the time was in favour of the restoration of Dutch colonial power.

In his student years, Schoorl was open to the political transformations taking place in Indonesia. Perhaps more importantly, he acquired a deep fascination for Indonesian culture. He majored in courses given by J.P.B. de Josselin de Jong, one of the foremost anthropologists of the time. On his graduation, Schoorl's expanding network brought him to the attention of Jan van Baal, who had become an established anthropologist before the war, and in the early 1950s was a member of parliament for the Anti-Revolutionaire Partij (ARP). Soon afterwards, Van Baal became governor of Papua New Guinea. So, quite unexpectedly, in 1952 Schoorl landed a job in the new Dutch colonial administration of Papua New Guinea.

Often this first job for Schoorl as a colonial adminstrator has been seen as a logical consequence of his choice of study. But this view does not do him justice. His first job as an administrator in Papua was not the 'logical' outcome of studying Indology in the late 1940s. At Leiden, his primary fascination had been cultural: the study of Indonesian culture. His passion was not for an administrative job: he had sought contact with local people, staff, and (Indonesian) students, who supported the political independence of Indonesia. If there was a clear path, it was zigzagging.

1 In the Netherlands, the Nederlandse Hervormde Kerk (Netherlands Reformed Church) and the Gereformeerde Kerken in Nederland (Reformed Churches in the Netherlands) represented two different Christian denominations. These have now fused. 
In 1996, after his retirement, Schoorl edited an important volume on the final years of the Dutch administration of Papua New Guinea. It contains 25 stories written by 17 Dutch former civil servants, including himself, about their work, each in a different region. Schoorl also wrote the introduction. My focus here is on Schoorl himself, the views which guided him personally, and the line of work that these required him to take. In his introduction, Schoorl describes administrators as 'agents of development'. He implies that administration is primarily focused on interventions, in all sorts of guises. His personal archives provide additional insights that broaden our understanding of how Schoorl's profile as a civil servant was shaped. Two points are important in his personal outlook as a civil servant. First, he held the view that the administration should not only intervene, but should also at times abstain from intervening in local affairs. Second, he felt the need to regularly collect 'information' in order to move ahead meaningfully, that is, in keeping with the interests of the local communities. I feel that these two elements are important, and perhaps key to understanding how his outlook was shaped, first as an administrator, and later as a professor of development studies.

After his arrival, Schoorl was asked to carry out some research in Merauke, examining the living conditions of the labourers of the Nederlandsch NieuwGuinea Petroleum Maatschappij (NNG PM, Netherlands New Guinea Petroleum Company), on which he wrote a lengthy report. Later the governor regularly asked Schoorl to undertake all kinds of research jobs in support of other administrators in different regions, or in the capital, Hollandia. Schoorl was only a 'regular' assistant controller (assistent-controleur) in the Muyu area for a relatively short time. Research activities occupied him for most of his ten years in Papua. These activities also included fieldwork that formed the basis for his $\mathrm{PhD}$ thesis, defended at Leiden University in 1957 (Schoorl 1957). The governor, Jan van Baal, thought highly of his research activities. He provided him with the time needed to carry out fieldwork in the Muyu area, to write his manuscript and to defend it in Leiden.

For Van Baal and Schoorl, research was not an isolated practice divorced from administration. When Schoorl collected 'information', he was not a 'positivist', collecting 'data' to prepare a 'pure', scientific, and theoretically grounded analysis. Information gathering was, for him, always carried out with a particular purpose in mind, rather than being an autonomous practice. Research and administration were clearly interrelated. The question, however, is how? And for what purpose?

On these questions Jan van Baal exposed him to highly nuanced and wideranging views, first as the director of the Bevolkingsinstituut (Population Insti- 
tute) of the government in Hollandia, and later as governor. Van Baal spelled out the great importance of 'information' for the colonial administration. He did so in 1954, in a policy paper of 20 pages, which is still one of the best that I have come across. The paper contained rich and subtle, nuanced reasoning, and a wisdom that we seem to have lost. Van Baal titled the policy paper simply as 'Notitie aan alle hoofden van zelfstandige kantoren en residenten' (A note to all heads of independent offices and residents). He sent it to all senior administrators, expressing his views and priorities, and how and why each of them should operate.

On the face of it, the 'note' affirmed official Dutch views as expressed by, the minister of overseas territories (minister van Overzeese Rijksdelen) in The Hague, W.J.A. Kernkamp (1952-1956). The core of beleid (policy) in Papua New Guinea should be ethical and moral — a noble-sounding characteristic indeed. But what did this imply? Van Baal's views, however, were not a replication of 'ethical policy' as defined by the authorities after 1901 in Indonesia. In his policy paper, Van Baal restored the Dutch concept of beleid to its original meaning: prudentia. That is, he primarily pleaded for great caution, for an awareness of contingency, and for the fact that if one did not know enough, one could not be certain of how to operate. He saw the imposition of views, moral or otherwise, on the local population as highly risky. Van Baal warned against making noble-sounding 'moral' promises. Such policies had often proven to be hazardous, leading to increased passivity among the population, and to a magical expectation of wonders and of great gifts falling from heaven. In short, to cargo cults.

Policymakers constantly needed new information as the risks related to intervention were clearly formidable. The idea that policy implied intervention in local societies had to be supplemented by another idea: that of restraint and caution, perhaps by the wisdom of not 'doing' much. This implied an acknowledgment of not knowing enough, an assumption of one's own ignorance, and of the possibility of hazardous, unintended consequences. Van Baal also stressed the need to study processes over the longer term. Once policies were being implemented, the situation might change in important ways. Policymaking was seen as a continuous learning practice. Van Baal suggested that cautious administrators should perhaps focus primarily on young people.

I found the note by Van Baal in Schoorl's personal archives. Underlined sentences indicate that he had read it carefully. Other archived documents supported Van Baal's view. In a public letter the prestigious Protestant missionary I.J. Kijne also strongly argued against making alluring 'promises' to the local population. These views had a great impact on the way in which Schoorl defined his role as a colonial administrator. By the time Van Baal left Papua 
Guinea, the two men, Van Baal and Schoorl, had become friendly. Van Baal became Schoorl's mentor and he later told me confidentially how much he admired the way Schoorl operated.

In 1962, at the end of his term, Schoorl was approached by the new Dutch governor with the offer of the job of director of the Bevolkingsinstituut in Hollandia. Indeed, he would have been the successor to Van Baal. At the same time, however, a second request was made: would he be willing to come to the Vrije Universiteit (vU) in Amsterdam and take up the chair of a new discipline, the sociology of non-Western societies?

Working as a Professor at the Vrije Universiteit, Amsterdam, 1962-1988

In 1962, aged 35, Schoorl became one of the youngest professors in the Netherlands. His new chair was to a large extent a continuation of his work in Papua. However, for Schoorl, the context was now quite different. Previously the freedom he had had to undertake research had been great. Now, paradoxically, it might be more restricted. What was the situation into which he walked, and how did he operate?

In 1962, the vU was part and parcel of a politically, religiously, and socially tightly integrated segment of society, called zuil (pillar) in Dutch. Each zuil (Reformed, socialist, or Catholic) controlled its boundaries and its autonomy in various ways. The 'border traffic' aross boundaries was restricted and this also applied to the vU. The vU even labelled its autonomy as 'sovereignty'. People who were not Reformed, or did not vote for the 'right' political party, were, in principle, denied access to the university. All students were required to take courses on Reformed religious and philosophical views in their first year. In 1962 control of the boundaries was firmly regulated.

However, the newly founded Faculty of Social Sciences provided new openings too. Social scientific research was now officially welcome. This entailed the possibility that conventional—Reformed — religious and philosophical 'truthclaims' would be supplemented, or perhaps even contradicted, by the legitimate new outcomes of social scientific research. In his new job Schoorl, like his colleagues, thus confronted an important tension. Official views were rather strongly imposed and some outcomes of research would be more welcome than others.

For more than seven years, the tension at the vu was very real and affected Schoorl's work, much as it did that of the other chairholders in the new faculty. In 1965 a sitting member of faculty staff was asked to leave, after he 'admitted' 
having voted for the socialist party. He left. 'Dissidents' had a serious problem. The new context was perhaps more constraining than the political climate in Papua New Guinea had been. The establishment of new chairs, including Schoorl's, required subtle handling of the tensions and, perhaps most of all, the avoidance of open conflict with official views.

In these formative years, the various disciplines responded in similar ways: the notion of responsibility was taken as the starting point for various research agendas. Emphasis was placed on the questions of how responsibility might be taken up, how it might be given direction, and how it might be implemented. In most agendas the importance of a sense of optimism was stressed; for example, the notion of rationality took centre stage in the political sciences. Schoorl proved equally optimistic about the possibility of 'rationality' in policymaking. His almost naïve description of the planning processes stands to prove this. It was assumed that the various phases and different dimensions, and all kinds of networks in different places, would fit together rather neatly. Another chair focused on the topic of 'aid'. The assumption at the time was that, in principle, aid was the opposite and an alternative to the exercise of power! Purity was assumed. Would it be an exaggeration to say that I can sense a connection here with the need to start playing it safe? The assumption of rational policymaking, of the purity of aid, and Schoorl's optimism about planned interventions in development all focus on administrative means and do not concern themselves with goals. As a result, clearly greater autonomy could be achieved; wider research agendas were formulated and extended as the heavy hand on the controls of Reformed identity mellowed and this identity was transformed.

The volume Religion and development (Quarles van Ufford and Schoffeleers 1988), produced when Schoorl retired, mirrors the great and significant impact that he had. The book presents a rich diversity of often innovative views on two themes dear to him: religion and development. The volume did not indicate that his own views on development were shared by an admiring ring of followers. No. He was honoured by his colleagues and staff members for creating more space and diversity, more freedom. In my view it was an appropriate token of our gratitude, and an indicator of his significance.

It is important to note that Schoorl worked closely with his colleagues at the vu. Their outlooks had also been shaped by their position on the very periphery of the Reformed pillar and, moreover, on the periphery in Indonesia. Thus the strict defence of truth-claims and the imposition of constraints by the leadership of the vu were also new to them. Schoorl's closest colleague, H.G. Schulte Nordholt, who became professor of anthropology, had been a colonial administrator in Timor. For him ecumenical relations had been part of the daily routine. As an administrator he had also been free to engage in the study of Timorese 
culture. This similarity in background allowed for close and fertile collaboration with Schoorl. Onvlee, the founding father of the disciplines, had a similarly ecumenical background. Like Schoorl, he had studied in Leiden, being admired there for his work, as 'smilingly' noted in his retirement speech. His free disposition had been evident during his student days, when he joined the Nederlandse Christen-Studentenvereniging (NCSV, Dutch Christian Students Movement), even though the synod of the Reformed Churches had strongly advised against membership. Therefore Schoorl's subsequent success and ensuing encouragement of greater diversity was the outcome of holding views that he shared with others.

For Schoorl in particular, the linking of scientific research and policymaking in this new and open manner remained the focus. While increasingly the autonomy of academic research was stressed, focusing on theory, 'data', and engaging in debate with colleagues in the discipline, time and again new and wider networks were created. Several of the new staff members engaged not only in 'free' academic research, but embarked on studies in critical communication with others: development agencies, religious bodies, and governmental —Dutch or otherwise - and international organizations. This led to a substantial number of research projects. These acquired an important dimension, particularly in Schoorl's department. The first example concerned a yearlong study of the motives and the various trajectories of people moving in large numbers from, for example, Morocco or Turkey to the Netherlands (Remplod, Reintegration of Emigrant Manpower and Local Opportunities for Development). It became clear, for instance, that these people were often not 'the poor', but the better off. The results of this research led to fascinating discussions with the government, producing unexpected insights about its conflicting interests, as the government officially wanted to know as well as sometimes refused to acknowledge specific outcomes of research. Thus new avenues of questioning and research opened up. Another important study programme focused on the processes of slum improvement in Karachi, Pakistan. This led to a better insight into the constraints under which various actors, including the government and private agencies, operated, and consequently also to knowledge of the pitfalls of external interventions and aid provision. Yet another programme studied new, primary-health-care initiatives implemented by the Dewan Gereja-Gereja Indonesia (DGI, Council of Churches in Indonesia). These initiatives experimented with bringing health care into the local communities. A study was carried out in collaboration with Gadjah Mada University in Yogyakarta. It was called Hedera, an abbreviation of 'health development in rural areas'. The results of this research led to exploratory consultations between various private actors and the Indonesian government. 
Schoorl was always involved in the running of these innovative research initiatives. He provided space, strengthening and supporting his staff members who initiated these programmes. Later, as part of a different initiative, a small group of actors, including university academics and staff members from various development agencies and governmental and non-governmental organizations, collaborated to create a new public space that cut across various boundaries. This led to the holding of a number of widely attended conferences and the publication of books and other documents (Agora). This initiative lasted for almost fifteen years. A fertile international network of German, English, and Dutch anthropologists was also created (Eidos), which operated for more than 20 years, hosting a large number of international conferences on all kinds of dimensions of development, and producing a series of books with a distinguished publisher.

All of these initiatives were actively supported by Schoorl, even after his retirement. His engagement, alongside his supervision of a great number of doctorates, stimulated an ever-increasing range and variety of academic research.

In the longer run, the vU, which was also transformed and opened up, endorsed and stimulated these increasingly diverse initiatives. The tensions early on had been overcome: the prudent beginning in 1962 was followed by a much wider diversity of questioning and debate that cut across conventional boundaries. The new space and freedom given to Schoorl's department were put to good use. Within the university, relations between the faculty and the board of directors became mutually supportive and beneficial. Until his retirement in 1988, Pim Schoorl was the central man and driving force behind this.

\section{4}

\section{Taking Early Retirement}

When Schoorl retired in 1988 he was 61 years old. He had silently been preparing for his departure already for four years! Despite this, his energy had clearly dimimished little. Why, then, did he retire so early? Had he perhaps smelled the first odours of a new surge of new and monopolistic truth-claims, soon to be imposed through a series of increasingly restrictive administrative rulings that encompassed the university's core scientific work, limiting the space for diversity and freedom? The rumblings of new-now secularmechanisms of constraint and control were making themselves felt ever more strongly at Dutch universities, including the vu. Gradually the debate about 'goals' and 'responsibility' was deemed superfluous. People started to become fearful again. 
The significance of Schoorl's work had been the opening up of an earlier monopoly of truth-claims after he had taken up his chair in the social sciences faculty. Did he now feel that the dynamics of history had started to zigzag towards new, equally monopolistic truth-claims - ones which closed boundaries and focused on predefined results? Now secular actors and administrators had narrowed the notions of wider academic responsibility.

When he retired, did Schoorl step off this new carousel, this turning back of history? So it seems. He had done his part. Now it was up to others to take up the good work. After his retirement, Schoorl returned to the first love of his student years: the study of Indonesian cultures and acculturation at the KITLV.

Pim Schoorl was married to Anna Emma (Annie) van der Meulen. She was his partner in his working life, acutely aware of all its dynamics and turns. Their journeys to Leiden, Papua, and Amsterdam, and Leiden again were a joint affair. The many letters to and from Annie Schoorl, written in the different phases of their life, stand as proof of this. By archiving these very personal letters, Pim demonstrated that theirs had been a shared journey. In his student years, when travelling to various places in Papua New Guinea, they always wrote to each other.

After their return to the Netherlands, Annie held various posts in the mission of the RCN, which took her to many places, particularly Pakistan. She was jointly responsible for many of their contacts with all kinds of Protestant missionary bodies. When I discussed items related to missionary work with Pim, Annie was often in the thick of the debate, being highly informed and modest too. Their marriage was one of shared involvement and shared modesty. Her views were of the greatest importance to him. A close colleague remarked on his retirement that Schoorl's significance was shared with his wife. Overcoming the tragic death of two children in their lifetime, their bond had become cemented to the core. Annie Schoorl died in 2011, a few years before him.

Pim had many long-term friends overseas, primarily in Indonesia and especially in Papua. They mourned his death too, grateful to have known him. In Indonesia, many of his friends came from Central Java, especially the Percik research agency and Satya Wacana University in Salatiga. Some of his oldest Indonesian friends came from Buton. In Papua, too, many mourned the loss of Pim. In the last decade he had renewed many of his contacts there. These were all personal relationships, forged over a long period of time. 
To end, a personal note. Our relationship started early in 1966, when preparations were being made by the Foreign Office in The Hague and the mission of the NRC in Oegstgeest to send me to Salatiga, Central Java, to help set up a research institute at Satya Wacana University. Pim suggested that his department at the vU would like to be involved too. All agreed. It was then that our acquaintance began. When I returned early, after a tragic family event, Pim asked me to join his department at the vU. It was the beginning of a life-long collaboration and friendship.

Three weeks before before his death, Pim phoned me to ask if I had heard that a good friend, Sjoerd Gerbrandy, had died. I had not. Not long before this phone call, I had visited Pim, who was clearly weakening, and was losing the ability to walk. Was the end coming? I had told him of a conversation I had had with Gerbrandy, professor of law at the vU, an elderly man and a mutual friend. We had discussed his church's opaque mix of political and religious dimensions. Gerbrandy had told me how he had been raised by his parents. They had not forced certain truths upon him, nor had they demanded he led a specific lifestyle or accepted religious dogmas and the Heidelberg catechismus. Rather, they had taught him through simple expressions of personal faith and piety. Gerbrandy had explained to me how this upbringing had shielded him from the pains caused by the constraints of his religion. As a child he had learned to distinguish between faith and the Christian religion, understanding that while the two are of course related, they are also often in opposition. As Pim called me back, was he, perhaps, gently hinting that he was approaching his last journey too; on the move for the last time? Adieu.

\section{References}

Quarles van Ufford, P. and J.M. Schoffeleers (eds) (1988). Religion and development.

Towards an integrated approach. Amsterdam: Free University Press.

Schoorl, J.W. (1957). Kultuur en kultuurveranderingen in het Moejoegebied. Den Haag: Voorhoeve. 